NOTICE: this is the author's version of a work that was accepted for publication in Materials and Design. Changes resulting from the publishing process, such as peer review, editing, corrections, structural formatting, and other quality control mechanisms may not be reflected in this document. Changes may have been made to this work since it was submitted for publication. A definitive version was subsequently published in Materials and Design, Vol. 63 (2014). DOI: 10.1016/j.matdes.2014.06.059 


\title{
Effect of fire exposure on cracking, spalling and residual strength of fly ash geopolymer concrete
}

\author{
Prabir Kumar Sarker ${ }^{\mathrm{a} \otimes}$, Sean Kelly ${ }^{\mathrm{b}}$ and Zhitong Yao ${ }^{\mathrm{c}}$ \\ a Department of Civil Engineering, Curtin University, Perth, WA 6102, Australia, Email: \\ p.sarker@curtin.edu.au , Phone: +61 892667568 \\ ${ }^{\mathrm{b}}$ Structural Systems Limited, Brisbane, Australia. \\ ${ }^{\mathrm{c}}$ College of Materials Science and Environmental Engineering, Hangzhou Dianzi University, Hangzhou \\ 310018, China. \\ ${ }^{\square}$ Corresponding author
}

\begin{abstract}
Fly ash based geopolymer is an emerging alternative binder to cement for making concrete. The cracking, spalling and residual strength behaviors of geopolymer concrete were studied in order to understand its fire endurance, which is essential for its use as a building material. Fly ash based geopolymer and ordinary portland cement (OPC) concrete cylinder specimens were exposed to fires at different temperatures up to $1000{ }^{\circ} \mathrm{C}$, with a heating rate of that given in the International Standards Organization (ISO) 834 standard. Compressive strength of the concretes varied in the range of 39 to $58 \mathrm{MPa}$. After the fire exposures, the geopolymer concrete specimens were found to suffer less damage in terms of cracking than the OPC concrete specimens. The OPC concrete cylinders suffered severe spalling for 800 and $1000{ }^{\circ} \mathrm{C}$ exposures, while there was no spalling in the geopolymer concrete specimens. The geopolymer concrete specimens generally retained higher strength than the OPC concrete specimens. The Scanning Electron Microscope (SEM) images of geopolymer concrete showed continued densification of the microstructure with the increase of fire temperature. The strength loss in the geopolymer concrete specimens was mainly because of the difference between the thermal expansions of geopolymer matrix and the aggregates.
\end{abstract}

Keywords: fly ash, geopolymer concrete, post-fire strength, spalling. 


\section{Introduction}

The global demand of concrete continues to increase in order to meet the increasing demand of infrastructures. Ordinary portland cement (OPC) has been traditionally used as the binder for concrete. However, cement production is associated with the emission of considerable amount of greenhouse gases. Therefore, development of alternative binders utilising industrial by-products is considered vital to help reduce the carbon footprint of concrete production. Geopolymer is an emerging alternative binding agent that uses an industrial byproduct material instead of cement. A base material that is rich in silicon (Si) and aluminum (Al) is reacted by an alkaline solution to produce the geopolymer binder. The base material for geopolymerisation can be a single material or combination of various materials. Materials such as low calcium fly ash [1, 2], high calcium fly ash [3], metakaolin [4], blast furnace slag $[5,6]$ and a combination of fly ash and blast furnace slag [7] have been used to produce geopolymer binders. Although different source materials can be used to manufacture geopolymer binders, low-calcium fly ash has been extensively used and found to be the most practical source material suitable for concrete applications. The coal-fired power stations generate substantial amount of fly ash as by-products. Therefore, the use of fly ash based geopolymer concrete (GPC) in constructions have the potential to reduce the carbon footprint of concrete manufacture.

The results of recent studies [8-11] have shown the effectiveness of low-calcium fly ash based geopolymer concrete as a construction material. As a relatively new construction material, it is essential to study the performance of geopolymer concrete in various structural applications. The previous research on fly ash based geopolymer concrete studied numerous short-term and long-term properties. Various parameters influencing the strength of geopolymer concrete were investigated [1, 2]. It was shown that heat-cured geopolymer

concrete possesses high compressive strength, undergoes low drying shrinkage and moderately low creep, and shows good resistance to aggressive agents such as sulphate. Geopolymer concrete shows good bond strength with reinforcing steel, which is essential for 
its function as a composite material in reinforced concrete structures [9]. Reinforced geopolymer concrete beams and columns showed similar behavior to that of traditional OPC concrete members [12-15]. Therefore, heat-cured fly ash based geopolymer concrete is considered as an ideal construction material for precast concrete elements such as beams, columns, slabs, walls and similar other structural members for building constructions.

In addition to other structural behaviors, it is vital to understand the fire endurance of a construction material in order to ensure safety for life and property. The extent of cracking, spalling and residual strength of a material after exposure to high temperature fire gives indication of the fire endurance of the material. This paper presents a study on the fire endurance of fly ash based geopolymer concrete.

Molecular structures are stable at certain temperatures. This stability is affected when the temperature conditions change. The temperature level is the fundamental parameter that affects molecular structure and hence is responsible for material deterioration. Exposure time and heating rates are also important parameters. In a composite material such as concrete, the difference between the thermal expansions of the aggregates and the binder matrix causes stresses at the interface which may result in cracking. Despite being classified as an indirect effect of temperature, micro cracking due to incompatible expansion can be the main cause of failure of a composite material in a fire. The molecular changes and microstructural stresses cause deterioration of compressive strength and other mechanical properties of the material.

Portland cement based concrete is a composite material that mainly consists of aggregates, cement and water. It is a reasonably dense and porous material, and it undergoes the damage mechanisms in fire. Khoury [16] proposed dissociation of $\mathrm{Ca}(\mathrm{OH})_{2}$ at $300-400{ }^{\circ} \mathrm{C}$, massive and sudden creep, usually causing failure at $600{ }^{\circ} \mathrm{C}$, dissociation of $\mathrm{CaCO}_{3}$ at $700{ }^{\circ} \mathrm{C}$, ceramic binding and complete water loss at $800{ }^{\circ} \mathrm{C}$ and melting at $1200-1350{ }^{\circ} \mathrm{C}$. Hiekal [17] found that $\mathrm{Ca}(\mathrm{OH})_{2}$ dehydrated between 500 and $600{ }^{\circ} \mathrm{C}$. Mohamedbhai [18] studied the effects of exposure time and rates of cooling on residual strength of heated concrete, using $100 \mathrm{~mm}$ cubic samples. The exposure time of 1 to 2 hours was found to be enough for the 
temperature to penetrate the $100 \mathrm{~mm}$ cubic samples and cause most of the compressive strength loss. The effect of higher temperature reduced the time required to cause strength loss, which is related to the increase of thermal conductivity at higher temperatures. After 1 hour exposure, the residual strength was 80, 70, 60 and 30\% for 200, 400, 600 and $800{ }^{\circ} \mathrm{C}$ respectively. Rates of heating and cooling showed no effect on the residual strength of concrete heated to $600{ }^{\circ} \mathrm{C}$ and beyond, but had some effect at lower temperatures, possibly due to the buildup of pore pressure. The effects of cooling on concrete were examined by Khoury et. al. [19]. Cooling strains (shrinkage) was found to be a function of the aggregate cement interaction causing cracking and not related to concrete age, initial moisture content or heating rate.

Poon et al. [20] studied normal and high strength concretes with pozzolanic materials. Metakaolin concrete increased strength up to $200{ }^{\circ} \mathrm{C}$, and maintained higher strengths up to $400{ }^{\circ} \mathrm{C}$ than fly-ash concrete, silica fume concrete and normal OPC concrete. After $400{ }^{\circ} \mathrm{C}$ all the high strength concretes rapidly deteriorated. The metakaolin concrete had the lowest final residual compressive strength despite showing better early strength gain, indicating that it is particularly susceptible to a certain high temperature range. Variations in the performance of pozzolanic concretes in high temperature exposure are common. High early strength gains and good stability between 200 and $400{ }^{\circ} \mathrm{C}$ followed by rapid deterioration and final compressive strength lower than normal concrete is commonly reported [20, 21]. Li et al [22] studied the effect of high temperature heat and strain rate on the residual strength of ternary blended concrete containing fly ash and silica fume. Remarkable strength loss was reported after $400{ }^{\circ} \mathrm{C}$.

Kong and Sanjayan [23] reported a 25\% reduction in compressive strength of $25 \mathrm{~mm}$ cube metakaolin based geopolymer paste specimens after 10 minutes exposure at $800{ }^{\circ} \mathrm{C}$. Cheng and Chiu [24] conducted tests on $10 \mathrm{~mm}$ thick small geopolymer panels made of metakaolin and granulated slag filler. One side of the panel was exposed to $1100{ }^{\circ} \mathrm{C}$ heat and the temperature on the other side was measured as $350{ }^{\circ} \mathrm{C}$ after 35 minutes. As a relatively new material, test results on the behavior of fly ash based geopolymer concrete subjected to fires 
at different temperature are scarce in literature. Some initial studies [25, 26] showed that fly ash geopolymers gained strength at exposure to relatively low temperature heat such as 200 ${ }^{\circ} \mathrm{C}$ and lost strength at exposure to heats of higher temperature. Therefore, a comprehensive study was conducted to understand the changes that occur in low-calcium fly ash based geopolymer concrete when subjected to fires at higher temperatures. This paper presents a study on the behavior of geopolymer concrete specimens exposed to fires at temperature up to $1000{ }^{\circ} \mathrm{C}$. The specimens were exposed to fires of different peak temperatures following the heating rate of ISO 834 [27] fire curve in a gas fired furnace. The peak temperature was maintained for certain duration and then the specimens were cooled down to room temperature. The extent of heating inside the specimens and the resulting cracking and spalling were observed before conducting the compression tests to determine the post-fire residual strengths. Companion OPC concrete specimens were subjected to fires of same temperature profile and tested similarly. Comparisons are then made between the results obtained for the two types of concrete experiencing the same fire exposure.

\section{Experimental details}

Fire has a significant impact on materials. A building fire can reach $850{ }^{\circ} \mathrm{C}$ in less than 30 minutes, and peak at around $1000{ }^{\circ} \mathrm{C}$ within 2 hours. A petrochemical fire can reach $900{ }^{\circ} \mathrm{C}$ within the first 5 minutes and peak at around $1100{ }^{\circ} \mathrm{C}$. Tunnel fires have similar heating rate to petrochemical fires but can reach $1350{ }^{\circ} \mathrm{C}$ in the first hour [16]. Design codes such as ISO 834 [27] and AS 1530 [28] provide standard fire curves for testing of materials though a real fire can be different in different situations because the parameters like combustibility of the material, location, humidity and air flow are not likely to be the same in any two fires.

In this study, standard $100 \mathrm{~mm} \times 200 \mathrm{~mm}$ geopolymer and OPC concrete cylinder specimens were subjected to fires up to $1000{ }^{\circ} \mathrm{C}$ with the heating rate similar to that of ISO 834 standard. Both types of concrete cylinders were exposed to identical temperature profile and the transfer of heat inside the specimens was recorded by using thermocouples. The damages in terms of cracking and spalling of the specimens during fire exposure and after cooling 
down to room temperature were determined. The specimens were then weighed to determine the mass loss and subjected to compression tests to determine the residual strengths. Scanning electron microscopic images were obtained to observe the microstructure of the geopolymer matrix after exposure to high temperature fires.

\subsection{Materials}

Concrete was mixed in the laboratory to cast the test specimens. General purpose Portland cement was used for OPC concrete. Commercially available Class F (ASTM: C618) fly ash was used to manufacture geopolymer concrete. The percentage of the fly ash passing through a $45 \mu \mathrm{m}$ sieve was $75 \%$. The chemical compositions of the cement and fly ash are given in Table 1. The alkaline liquids for geopolymer concrete were sodium hydroxide and sodium silicate solutions. Commercial sodium hydroxide pellets were dissolved in water to make $14 \mathrm{M}$ solution. The sodium silicate solution had a mass composition of $14.7 \% \mathrm{Na}_{2} \mathrm{O}, 29.4 \%$ $\mathrm{SiO}_{2}$, and $55.9 \%$ water. Both the liquids were mixed together before adding to fly ash and aggregates. The coarse aggregates were 10 and $20 \mathrm{~mm}$ nominal size crushed granites. The sand used was river sand. Tap water was used in mixing of the concretes. The mixture proportions of the OPC and geopolymer concretes are given in Table 2. The concretes were mixed in a pan type laboratory concrete mixer. Standard slump tests were carried out to determine the workability of fresh concrete. The slump value of OPC concrete was $100 \mathrm{~mm}$ and that of geopolymer concrete was $250 \mathrm{~mm}$. Both the concretes had reasonable workability at these values of slump.

\subsection{Casting and curing of test specimens}

Standard $100 \mathrm{~mm} \times 200 \mathrm{~mm}$ cylinders were cast using the OPC and GPC mixtures given in Table 2. Some of the freshly cast cylinder specimens are shown in Figure 1. As shown in Figure 2, a thermocouple was inserted at the centre of some cylinders to measure the

temperature at that point during heating of the cylinders inside the furnace. The OPC concrete specimens were cured in water and the geopolymer concrete specimens were heat- 
cured by using steam. The geopolymer concrete cylinders were divided into two groups and subjected to two different curing regimes. The specimens of the first group were subjected to steam curing at $60{ }^{\circ} \mathrm{C}$ for 24 hours immediately after casting. Steam curing of the second group of specimens started three days after casting and the curing was done at $80{ }^{\circ} \mathrm{C}$ for 24 hours. It was shown by Hardjito et al. [29] that strength of geopolymer concrete increased by increasing of the curing temperature and applying a rest period of up to three days before the start of the steam curing. Therefore, different curing regimes were used to the geopolymer concrete cylinders to achieve a normal strength and a higher strength after the different types of steam curing regimes. The cylinders of the first curing regime are designated by GPN and those of the second curing regime are designated as GPH.

\subsection{Test procedure}

The specimens were exposed to fire at the age of 28 days after casting. Figure 3 shows a set of cylinders inside the gas fired furnace ready for fire exposure. The door of the furnace was closed and the flame was increased by controlling the flow of gas. This condition of heating the cylinders simulated heating of the concrete from all the sides. This heating is considered to be critical for damage of the concrete by differential temperature between the external surface and inside of the cylinder. The door of the furnace was kept closed during the heating period. The geopolymer and OPC concrete specimens were exposed to fire in the same way. The fire in the furnace was controlled to achieve the initial heating rate of the temperaturetime curve recommended in the standards for fire test of building materials. The temperaturetime curve recommended in the Australian standard [28] is given by Equation 1.

$T_{t}=T_{0}+345 \log _{10}(8 t+1)$

Where $T_{t}$ is furnace temperature $\left({ }^{\circ} \mathrm{C}\right)$ at time $\mathrm{t}$ (minutes) and $T_{o}$ is the initial furnace temperature $\left({ }^{\circ} \mathrm{C}\right)$. 
The temperature of the air inside the furnace was measured by an in-built thermocouple of the furnace. The temperature at the centre of the cylinder was measured by a K-type thermocouple inserted in the specimens during casting. The thermocouples were connected to electronic data loggers that recorded the measured temperatures. The cylinders were subjected to the peak temperatures of $400,650,800$ and $1000{ }^{\circ} \mathrm{C}$. Once the desired peak temperature of the furnace air was achieved, it was maintained in order to raise the

temperature inside the cylinder. As expected, the temperature rise at the centre of the cylinder was slower than that of the furnace air. The cylinders were heated for duration of 150 minutes. The temperature at the centre of the cylinders reached the peak furnace air temperature during the heating period. The typical temperature - time variations of the furnace air and at the centre of the cylinders are shown in Figures 4 and 5. The furnace was turned off after heating the specimens for 150 minutes and the specimens were then left to cool down to room temperature by opening the door of the furnace. After cooling down to room temperature, the specimens were tested for concentric compression using a universal testing machine.

\section{Test Results and Discussion}

\subsection{Development of compressive strength}

The concrete specimens were tested for compressive strengths at different ages up to 28 days to determine the strength development before exposure to fire. The OPC concrete cylinders were subjected to water curing and the geopolymer concrete cylinders were subjected to two different regimes of steam curing. The geopolymer concrete specimens of group GPN were steam-cured at $60{ }^{\circ} \mathrm{C}$ immediately after casting and those of group GPH were given a rest period of 3 days before beginning of the steam-curing at $80{ }^{\circ} \mathrm{C}$. The strength developments of the three types of concrete are shown in Figure 6. It can be seen from the figure that the rest period and higher curing temperature contributed to an increase in strength of the geopolymer concrete specimens of group GPH as compared to the specimens of group GPN. There was very little gain in strength in the geopolymer concrete specimens after completion 
of the steam curing. As usual, strength of the OPC concrete specimens continued to increase gradually to the age of 28 days. The trends of strength development in the geopolymer concrete specimens are similar to those observed by Hardjito et. al. [29].

\subsection{Transfer of heat inside concrete}

Typical temperature - time curves recorded in the centre of the concrete cylinders exposed to fire are shown in Figures 4 and 5. It can be seen that generally the temperatures at the centre of the geopolymer concrete specimens were higher than those of the OPC concrete cylinders at a given time when the specimens of both types of concrete were subjected to same furnace air temperature. Thus, the peak temperature reached the centre of the geopolymer concrete specimens earlier than in the OPC concrete specimens. This indicates a higher conductivity of the geopolymer concrete as compared to that of the OPC concrete at elevated temperature. This can be considered to be because of the higher content of metal ions such as silicon, aluminium and iron in the fly ash based geopolymer matrix as compared to those in the OPC matrix. The higher contents of these metal oxides in fly ash than in OPC can be seen in Table 1.

\subsection{Cracking, spalling and change in appearance of the concrete specimens}

The changes in the physical appearance of the geopolymer concrete cylinders of group GPN and GPH are shown in Figures 7 and 8 respectively. There was an obvious colour change in geopolymer concrete after the exposure to the four different temperature ranges. At $400{ }^{\circ} \mathrm{C}$ there was not a huge change in colour for the geopolymer concrete samples, with both the GPN and GPH samples displaying a very similar surface colour with the GPH sample having only a slight light brown tinge to it. At $650{ }^{\circ} \mathrm{C}$, the geopolymer concrete specimens displayed a very similar surface colour, but it had changed to a light brown colour. At $800{ }^{\circ} \mathrm{C}$, there was a clear difference from the original colour with both the high and normal strength concretes displaying a dark red colour. Parts of the surface were quite black, but this was able to be rubbed off to reveal the earthy red colour below. At $1000{ }^{\circ} \mathrm{C}$, the red colour 
became very prominent, with the high strength geopolymer concrete being more distinctive than the normal strength geopolymer concrete. The colour changes of the geopolymer concrete samples were because of the high iron oxide content of the fly ash. A similar colour change to brown in fly ash geopolymers subjected to high temperature heat was also observed by Zhao and Sanjayan [30].

The changes in the physical appearance of the OPC concrete cylinders at different temperature exposures are shown in Figure 9. As shown in the figure, OPC concrete did not display much change in colour when exposed to various temperatures. The only visible difference was that the grey colour became slightly lighter after exposure to the higher temperature fires. This was due to the higher reduction of moisture in the specimens.

Due to the temperature differential between the surface and the centre of the specimens, surface cracking was very prominent in many of the samples after exposure to fire. The most noticeable surface cracking was found in the OPC concrete specimens, due to the rapid moisture loss of the concrete. The surface cracking has occurred also as a result of the differential strain which is caused by a temperature gradient through the cross section of the concrete. At some stages during the fire exposure, the temperature differential between the centre and surface of the specimens was as high as $600{ }^{\circ} \mathrm{C}$ which created large amount of differential strain. This huge differential strain caused large amounts of surface cracking, with more cracking evident in the samples exposed to the higher temperature ranges.

The cracks on the surface of specimens were generally evident after exposure to the higher temperature ranges. Heating of the inside of geopolymer concrete was faster and the temperature gradient between the surface and the core was higher in OPC concrete as indicated by the temperature profiles presented in Figures 4 and 5. This difference in the temperature gradients has an effect on the cracking of specimens. Surface cracking of the geopolymer concrete specimens was not as predominant as in the OPC concrete samples. The number and width of cracks occurred after exposure to $1000{ }^{\circ} \mathrm{C}$ fire were much smaller in geopolymer concrete specimens as compared to the OPC concrete specimens. These cracks were very small and difficult to see with the naked eye, as shown in Figures 7 and 8. 
However the cracks were still evident, but were generally observed to only temperatures above $800{ }^{\circ} \mathrm{C}$ for the geopolymer concrete specimens.

During fire exposures of the OPC concrete cylinders, there were a number of cases of spalling in the $800{ }^{\circ} \mathrm{C}$ and $1000{ }^{\circ} \mathrm{C}$ temperatures. The pieces of concrete spalled without any explosive sound. The reason for the spalling is the very rapid rise of the furnace air temperature, creating a large thermal gradient between the surface and the internal core of the concrete specimen. The fire temperature caused a rapid rise of the pore pressure in the concrete. This high pore pressure cannot escape the concrete rapidly, which creates a tensile stress in the concrete. Spalling occurs when the tensile stress in concrete caused by this pore pressure exceeds the tensile strength of concrete. The spalling of the OPC concrete cylinders at $800{ }^{\circ} \mathrm{C}$ and $1000{ }^{\circ} \mathrm{C}$ temperatures are shown in Figures 10 and 11 respectively. This type of spalling was not observed in the geopolymer concrete cylinders. A longitudinal section of a geopolymer concrete cylinder after exposure to $1000{ }^{\circ} \mathrm{C}$ fire is shown in Figure 12 . As shown in this figure, geopolymer concrete is found to remain mostly solid as compared to the considerable disintegration of OPC concrete shown in Figure 11. The reason for higher resistance against disintegration and spalling of the geopolymer concrete specimens is considered to be its inherent higher tensile strength than that of OPC concrete. It was shown by comparison of the test data on the splitting tensile strengths of OPC and geopolymer concrete that heat-cured fly ash based geopolymer concrete tends to have higher tensile strength than OPC concrete of the same compressive strength [9]. The extensive cracking and spalling of the OPC concrete indicates that this may reduce the effective cross-sectional area of an OPC concrete member when exposed to high temperature fire. Such reduction in the effective cross-sectional area may eventually reduce the load capacity of the OPC concrete member. The relatively less cracking and spalling of geopolymer concrete indicates its better endurance in fire as compared to OPC concrete.

\subsection{Residual strength of concrete after exposure to fire}

The mean compressive strengths obtained from the cylinder samples of GPN, GPH and OPC concrete before and after exposure to fires at different temperatures are given in Table 3 . The 
percentage residual strengths for each temperature exposure are also given in the table. It can be seen from the table that the normal strength geopolymer concrete gained some strength, with a residual strength of $107 \%$ after the $400{ }^{\circ} \mathrm{C}$ exposure temperature. After exposure to $400{ }^{\circ} \mathrm{C}$ temperature, the high strength geopolymer concrete and the OPC concrete had residual strengths of $93 \%$ and $90 \%$ respectively. Thus, the normal strength geopolymer concrete displayed considerably better residual strength than the high strength geopolymer and OPC concretes at this temperature. This is considered to be because of further geopolymerisation of the normal strength geopolymer concrete in the fire exposure.

It can be seen from Table 3 that all three types of concrete lost strength rapidly after $400{ }^{\circ} \mathrm{C}$ exposure. The normal strength geopolymer concrete displayed higher residual strength than the other two types of concrete up to $650{ }^{\circ} \mathrm{C}$ exposure. At this temperature range, the normal strength geopolymer concrete samples yielded a mean residual compressive strength of $83 \%$. The high strength geopolymer concrete and OPC concrete showed average residual strengths of $59 \%$ and $51 \%$ respectively. Thus, the normal strength geopolymer concrete retained higher percentage of strength than the high strength geopolymer concrete and OPC concrete after $650{ }^{\circ} \mathrm{C}$ exposure. This is because of additional reaction of the binder in the normal strength geopolymer concrete specimens by the heat of fire since they were initially cured at a lower temperature than the high strength geopolymer concrete specimens.

At $800^{\circ} \mathrm{C}$, there is generally complete loss of water in OPC concrete, which has a significant impact on the compressive strength of the sample. Because of this phase change, the residual strength of OPC concrete dropped from $51 \%$ to a very low of $21 \%$. Both the geopolymer concretes showed similar $(27-29 \%)$ residual strengths at this temperature range.

At $1000{ }^{\circ} \mathrm{C}$, the residual strengths were very low for all the tested mixtures. The GPH, GPN and OPC concrete samples retained average residual compressive strengths of $18 \%, 16 \%$ and $11 \%$ respectively. The severe strength loss of the specimens at this temperature occurred mainly because of the extensive cracking of the specimens. Furthermore, there was spalling of substrates in the OPC concrete specimens. The OPC concrete specimens suffered disintegration because of the greater loss of bonding between the binder and aggregates as a result of complete dehydration. The high thermal strain in the samples due to rapid heating 
rate of fire is the main contributing factor of the strength loss in concrete at this temperature. Generally, the less cracking and spalling, and higher residual compressive strength of fly ash based geopolymer concrete as compared to OPC concrete indicate its better performance after high temperature fire exposure. This observation is consistent with the higher fracture energy of geopolymer concrete as compared to OPC concrete of similar compressive strength, as shown in a previous study [31].

\subsection{Mass loss and microstructure of geopolymer concrete after exposure to fire}

The mass losses of the concrete samples due to fire exposure were determined from the masses of the cylinders before and after the fire exposure. The average values of mass loss in the three types of concrete after exposure to fires at different temperature are plotted in Figure 13. The exact values of the mass loss in the OPC concrete specimens could not be determined for exposures to fires at 800 and $1000{ }^{\circ} \mathrm{C}$ because of spalling of the specimens. However an increasing trend of the mass loss in the OPC concrete up to $650{ }^{\circ} \mathrm{C}$ can be seen in Figure 13.

The normal and high strength geopolymer concretes showed a similar mass loss curves, with relatively higher mass loss in the high strength geopolymer concrete. It can be seen from Figure 13 that most of the mass loss occurred at $400{ }^{\circ} \mathrm{C}$. The mass loss of the concretes at $400{ }^{\circ} \mathrm{C}$ was $2.5 \%$ and $4 \%$ for GPN and GPH respectively. The rate of mass loss reduced in the geopolymer concretes after this temperature while that of the OPC concrete continued at a similar rate until $650{ }^{\circ} \mathrm{C}$. The mass loss of the normal strength and high strength geopolymer concrete specimens at $1000{ }^{\circ} \mathrm{C}$ were $4.3 \%$ and $4.8 \%$ respectively.

The microstructures of the geopolymer concrete specimens subjected to high temperature fire were investigated by scanning electron microscopy (SEM). The SEM images of the GPN specimens after exposures to 650,800 and $1000{ }^{\circ} \mathrm{C}$ are shown in Figures 14 (a) to 14 (c). It can be seen from these figures that the geopolymer microstructures became denser with the increase of fire temperature up to $1000{ }^{\circ} \mathrm{C}$. This change has occurred in the microstructure because of sintering and further geopolymerisation of fly ash with the increase of 
temperature. Thus, the geopolymer microstructure remained stable after exposure to high temperature fires. This is consistent with the observation of Kong et al [32] that reported a $6 \%$ increase in strength of fly ash based geopolymer paste after exposure to heat of $800{ }^{\circ} \mathrm{C}$. The strength of geopolymer paste increased with the increasing compactness of the microstructure at this temperature. However, the strength loss of the concrete specimens after high temperature exposure is mainly because of the thermal shock and the incompatibility between thermal expansions of the geopolymer matrix and the aggregates. It was shown by Kong and Sanjayan [25] that the thermal expansions of geopolymer paste and aggregates were different at high temperature exposure. This difference in thermal expansions initiates the damages in concrete which eventually results in the reduction of compressive strength.

\section{Conclusions}

Low calcium fly ash based geopolymer concrete specimens were exposed to fires at 400 , 650,800 and $1000{ }^{\circ} \mathrm{C}$ with the temperature rising at a rate given in the standards for fire tests of construction materials. Companion OPC concrete cylinders were also exposed to fires of same temperature profile. The cracking, spalling, mass loss and residual strength of OPC and geopolymer concrete specimens were compared after exposure to fires at different temperatures. The microstructure of geopolymer concrete after exposure to high temperature fire was observed by SEM images. The following conclusions are drawn from the test results:

- Generally, heat travelled at a faster rate in geopolymer concrete than in OPC concrete when exposed to fire. This resulted in less temperature gradient inside geopolymer concrete than in the OPC concrete specimens. Significant changes in colour occurred in geopolymer concrete after exposure to temperatures above $650{ }^{\circ} \mathrm{C}$, ranging from brown to red.

- Significant spalling occurred in the OPC concrete specimens for fires at 800 and 1000 ${ }^{\circ} \mathrm{C}$. Such spalling did not occur in the geopolymer concrete specimens exposed to the same fire temperatures. Extensive surface cracking appeared in the OPC concrete 
cylinders after fire exposure to $400,650,800$ and $1000{ }^{\circ} \mathrm{C}$. However, only minor surface cracklings were observed in the geopolymer concrete specimens subjected to fire temperatures of at 800 and $1000{ }^{\circ} \mathrm{C}$. This shows a better resistance to spalling and cracking of geopolymer concrete in comparison to OPC concrete specimens in fire.

- After $400{ }^{\circ} \mathrm{C}$ fire, the average residual strength of geopolymer concretes were in the range of $93 \%$ and $107 \%$, and that of OPC concrete was $90 \%$. After $650{ }^{\circ} \mathrm{C}$, the residual strength of geopolymer concretes was between $59 \%$ and $82 \%$, and that of OPC concrete was $52 \%$. Thus, the geopolymer concrete retained higher percentage of strength than the OPC concrete specimens up to $650{ }^{\circ} \mathrm{C}$. The residual strengths of the concretes ranged from 21 to $29 \%$ and 11 to $16 \%$ after exposures to 800 and $1000{ }^{\circ} \mathrm{C}$ respectively.

- The average mass loss of geopolymer concrete was up to $4.8 \%$ after exposure to 1000 ${ }^{\circ} \mathrm{C}$, which was mainly because of the loss of moisture at the high temperature. The geopolymer microstructure remained stable and compact after exposure to high temperature fire. However, the strength loss of the concrete was mainly because of the strain developed by the differential expansions between geopolymer matrix and the aggregates.

\section{Acknowledgement}

The authors wish to gratefully acknowledge the use of a furnace in the Department of Arts, Curtin University. The authors also acknowledge the use of equipment, scientific and technical assistance of the Curtin University Electron Microscope Facility, which has been partially funded by the University, State and Commonwealth Governments. 


\section{REFERENCES}

1. Hardjito D, Wallah SE, Sumajouw DMJ, Rangan BV. On the development of fly ashbased geopolymer concrete. ACI Mater J, 2004; 101(6): 467-72.

2. Fernandez- Jimenez A, Palomo A. Engineering properties of alkali-activated fly ash concrete. ACI Mater J 2006; 103(2):106-12.

3. Chindaprasirt P, Chareerat T, Sirivivatnanon V. Workability and strength of coarse high calcium fly ash geopolymer. Cem. Concr. Comp. 2007; 29:224-29.

4. Davidovits J. High-alkali cements for 21st century concretes. ACI Special Publication. SP 144; 1994: P. 383-98.

5. Bakharev T, Sanjayan J, Cheng Y. Alkali activation of Australian slag cements. Cem. Concr. Res. 1999; 29:113-20.

6. Fernandez-Jimenez A, Palomo JG, Puertas F. Alkali activated slag mortars: mechanical strength behaviour. Cem. Concr. Res. 29 (1999) 1313-1321.

7. Deb PS, Nath P, Sarker PK. Strength and permeation properties of slag blended fly ash based geopolymer concrete. Advanced Mater. Res. 2013; 651: 168 - 173.

8. Rangan BV. Studies on low-calcium fly ash-based geopolymer concrete. Indian Concr. J. 2006; 80: 9-17.

9. Sarker PK. Bond strength of reinforcing steel embedded in geopolymer concrete. Mater. Struct. 2011; 44:1021-30.

10. Sarker PK. Analysis of geopolymer concrete columns, Mater. Struct. 2009; 42:715-24.

11. Fernandez- Jimenez A, Palomo A. Composition and microstructure of alkali activated fly ash binder: effect of the activator Cem. Concr. Res. 2005; 35:1984-92.

12. Sumajouw DMJ, Hardjito D, Wallah SE, Rangan BV. Fly ash-based geopolymer concrete: study of slender columns. J. Mater. Sci. 2007; 42:3124-30.

13. Sumajouw DMJ, Hardjito D, Wallah SE, Rangan BV. Flexural behavior of fly ash-based geopolymer concrete beams, Proceedings of the Concrete Institute of Australia 22nd Biennial Conference, 16 - 19 October, 2005, Melbourne, Australia,. 
14. Chang EH, Sarker PK, Lloyd N, Rangan BV. Shear behavior of reinforced fly ash-based geopolymer concrete beams, Proceedings of the Concrete Institute of Australia 23rd Biennial Conference, 18 - 20 October, 2007, 679 - 687, Adelaide, Australia.

15. Rahman M, Sarker PK. Geopolymer concrete columns under combined axial load and biaxial bending, CONCRETE 2011 Conference, 12-14 October, 2011, Perth, Western Australia.

16. Khoury GA. Effect of fire on concrete and concrete structures. Fire Concr. 2000; 2:42947.

17. Heikal M. Effect of temperature on the physico-mechanical and mineralogical properties of homra pozzolanic cement pastes. Cem. Concr. Res. 2000; 30:1835-39.

18. Mohamedbhai GTG. Effect of exposure time and rates of heating and cooling on residual strength of heated concrete. Mag. Concr. Res. 1986; 38:151-58.

19. Khoury GA, Grainger BN, Sullivan PJE. Strain of concrete during fast cooling form 600 ${ }^{\circ} \mathrm{C}$ under load. Mag. Concr. Res. 1986; 38:3-12.

20. Poon CS, Azhar S, Anson M, Wong YL. Performance of metakaolin concrete at elevated temperatures. Cem. Concr. Comp. 2003; 25: 83-89.

21. Papayianna I, Valliasis T, Heat deformations of fly ash concrete. Cem. Concr. Comp. 2005; 27: 249- 254.

22. Li, Z, Xu J, Bai E. Static and dynamic mechanical properties of concrete after high temperature exposure. Mater. Sci. Eng. A. 2012; 544:27 - 32.

23. Kong DLY, Sanjayan JG. Damage due to elevated temperatures in metakaolinite-based geopolymer pastes, International Workshop on Geopolymer and Geopolymer Concrete, September 28-29, 2005, Perth, Australia.

24. Cheng TW, Chiu JP. Fire-resistant Geopolymer Produced by Granulated Blast Furnace Slag. Miner. Eng. 2003; 16:205-10.

25. Kong DLY, Sanjayan JG. Damage behavior of geopolymer composites exposed to elevated temperatures. Cem. Concr. Comp. 2008; 30:986-91.

26. Sarker PK, de Meillon T. Geopolymer concrete after exposure to high temperature heat, Recent Developments in Structural Engineering, in A. Zingoni (ed.), Mechanics and Computation, Millpress, Rotterdam, The Netherlands, 2007, pp.1566 - 1571. 
27. ISO 834. International Standards Organization, Fire Resistance Tests, Elements of Building Construction, Switzerland, 1980.

28. AS 1530.4. Australian Standard, Methods for Fire Tests on Building Materials, Components and Structures, Australia, 1997.

29. Hardjito D, Rangan BV. Development and properties of low-calcium fly ash-based geopolymer concrete. Research Report GC1, Faculty of Engineering, Curtin University of Technology, Perth, Australia, 2005.

30. Zhao R, Sanjayan, JG. Geopolymer and portland cement concrete in simulated fire. Mag. Concr. Res. 2011; 63(3): 163-73.

31. Sarker PK, Haque R, Ramgolam KV. Fracture behaviour of heat cured fly ash geopolymer concrete. Mater. Des. 2013; 44: 580-6.

32. Kong DLY, Sanjayan JG, Sagoe-Crentsil K. Comparative performance of geopolymers made with metakaolin and fly ash after exposure to elevated temperatures. Cem. Concr. Res. 2007; 37: 1583-9. 
Table 1. Chemical compositions of cement and fly ash (mass \%)

\begin{tabular}{cllllllllll}
\hline Compounds & $\mathrm{SiO}_{2}$ & $\mathrm{Al}_{2} \mathrm{O}_{3}$ & $\mathrm{Fe}_{2} \mathrm{O}_{3}$ & $\mathrm{CaO}$ & $\mathrm{Na}_{2} \mathrm{O}$ & $\mathrm{K}_{2} \mathrm{O}$ & $\mathrm{TiO}_{2}$ & $\mathrm{MgO}$ & $\mathrm{P}_{2} \mathrm{O}_{5}$ & $\mathrm{SO}_{3}$ \\
\hline Cement & 20.4 & 4.8 & 2.9 & 64.2 & 0.29 & - & - & 2.0 & - & 2.4 \\
Fly ash & 50.8 & 26.9 & 13.5 & 2.05 & 0.33 & 0.57 & 1.57 & 1.33 & 1.46 & 0.31
\end{tabular}

Table 2. Mixture proportions of concrete $\left(\mathrm{kg} / \mathrm{m}^{3}\right)$

\begin{tabular}{|c|c|c|c|c|c|c|c|c|}
\hline \multirow[t]{2}{*}{$\begin{array}{l}\text { Mix- } \\
\text { ture }\end{array}$} & \multirow[t]{2}{*}{ Cement } & \multirow[t]{2}{*}{$\begin{array}{l}\text { Fly } \\
\text { ash }\end{array}$} & \multirow[t]{2}{*}{ Water } & \multirow{2}{*}{$\begin{array}{c}\text { Sodium } \\
\text { hydroxide }\end{array}$} & \multirow{2}{*}{$\begin{array}{l}\text { Sodium } \\
\text { silicate }\end{array}$} & \multirow[t]{2}{*}{ Sand } & \multicolumn{2}{|c|}{$\begin{array}{c}\text { Coarse } \\
\text { aggregate }\end{array}$} \\
\hline & & & & & & & $10 \mathrm{~mm}$ & $20 \mathrm{~mm}$ \\
\hline OPC & 334 & - & 177 & - & - & 643 & 404 & 860 \\
\hline GPC & - & 408 & 20 & 41 & 103 & 647 & 554 & 647 \\
\hline
\end{tabular}

Table 3. Compressive strength before fire and percentage residual strength after fire

\begin{tabular}{|c|c|c|c|c|c|c|}
\hline & GPN & & GPH & & $\mathrm{OPC}$ & \\
\hline $\begin{array}{c}\text { Temp. } \\
{ }^{\circ} \mathrm{C}\end{array}$ & $\begin{array}{c}\text { Compr. } \\
\text { strength } \\
f_{c m}(\mathrm{MPa}) \\
\text { (Std. dev) }\end{array}$ & $\begin{array}{c}\text { Residual } \\
\text { strength } \\
(\%)\end{array}$ & $\begin{array}{c}\text { Compr. } \\
\text { strength } \\
f_{c m}(\mathrm{MPa}) \\
\text { (Std. dev) }\end{array}$ & $\begin{array}{c}\text { Residual } \\
\text { strength } \\
(\%)\end{array}$ & $\begin{array}{c}\text { Compr. } \\
\text { strength } \\
f_{c m}(\mathrm{MPa}) \\
\text { (Std. dev) }\end{array}$ & $\begin{array}{c}\text { Residual } \\
\text { strength } \\
\text { (\%) }\end{array}$ \\
\hline 23 & $\begin{array}{c}39 \\
(2.2)\end{array}$ & 100 & $\begin{array}{c}58 \\
(3.5)\end{array}$ & 100 & $\begin{array}{c}42 \\
(2.6)\end{array}$ & 100 \\
\hline 400 & $\begin{array}{c}42 \\
(2.4)\end{array}$ & 107 & $\begin{array}{c}54 \\
(2.1)\end{array}$ & 93 & $\begin{array}{c}38 \\
(2.9)\end{array}$ & 90 \\
\hline 650 & $\begin{array}{c}32 \\
(2.9)\end{array}$ & 83 & $\begin{array}{c}34 \\
(1.8)\end{array}$ & 59 & $\begin{array}{c}22 \\
(2.2)\end{array}$ & 51 \\
\hline 800 & $\begin{array}{c}11 \\
(0.8)\end{array}$ & 27 & $\begin{array}{c}17 \\
(0.7)\end{array}$ & 29 & $\begin{array}{c}9 \\
(0.6)\end{array}$ & 21 \\
\hline 1000 & $\begin{array}{c}6 \\
(0.5)\end{array}$ & 16 & $\begin{array}{c}11 \\
(0.6)\end{array}$ & 18 & $\begin{array}{c}5 \\
(0.5)\end{array}$ & 12 \\
\hline
\end{tabular}




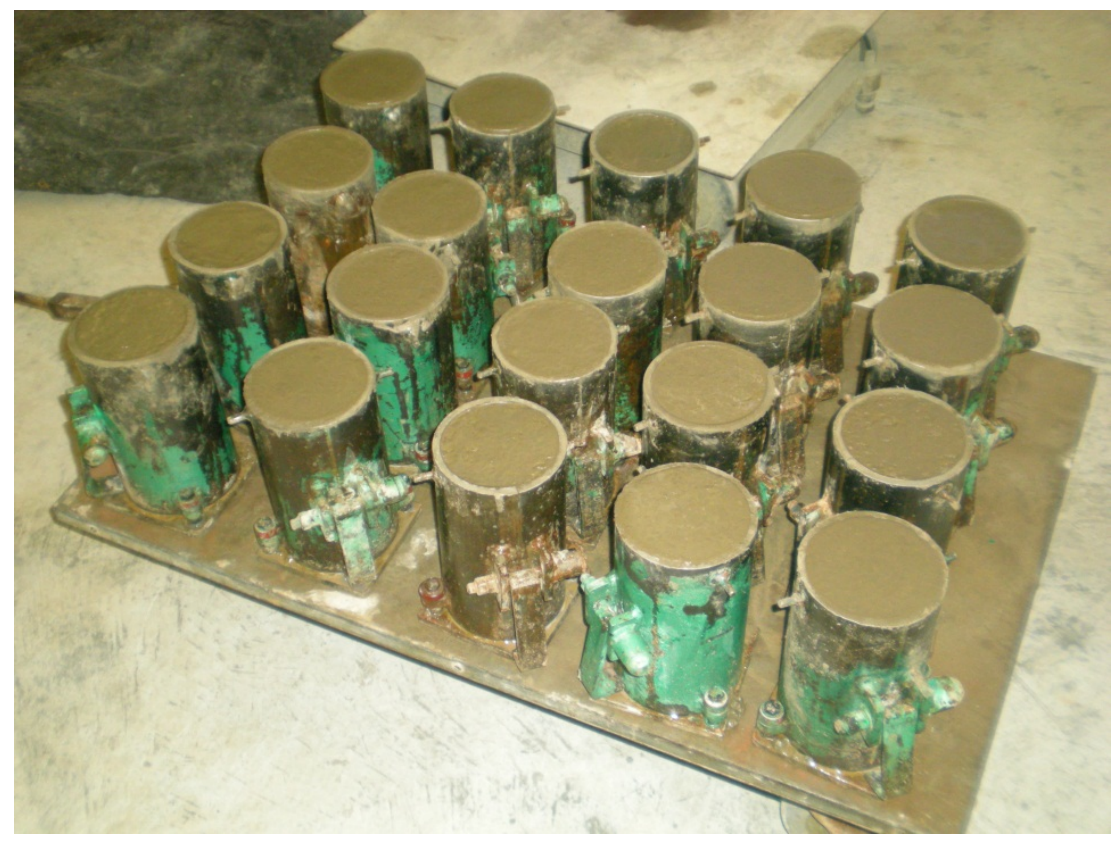

Figure 1. Concrete cylinder specimens after casting

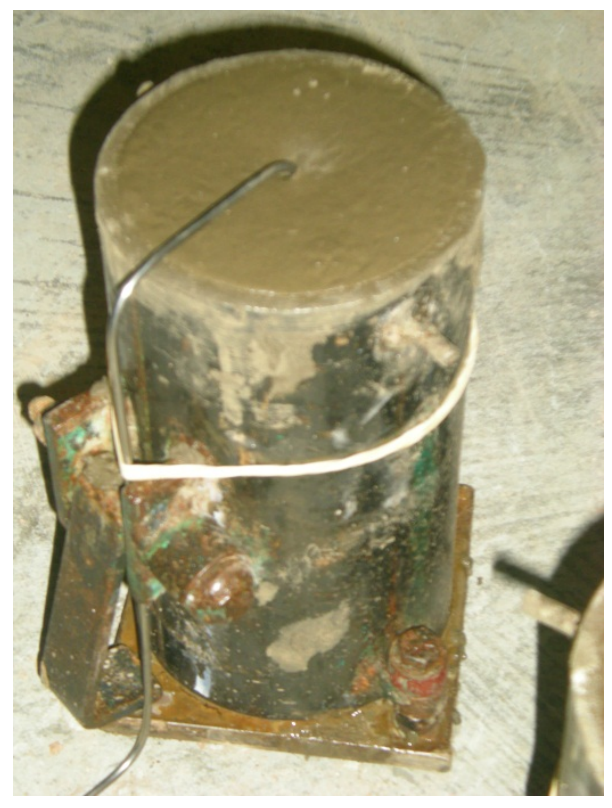

Figure 2. A typical concrete cylinder with thermocouple 


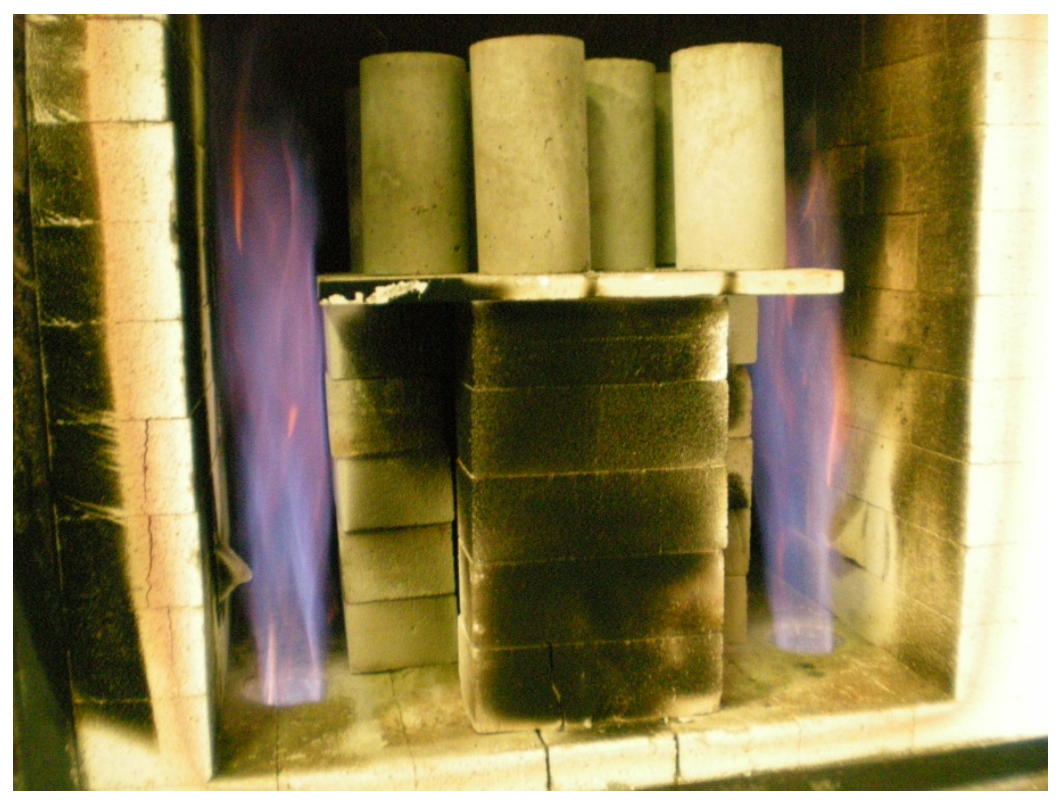

Figure 3. Cylinder specimens set up in furnace for fire exposure

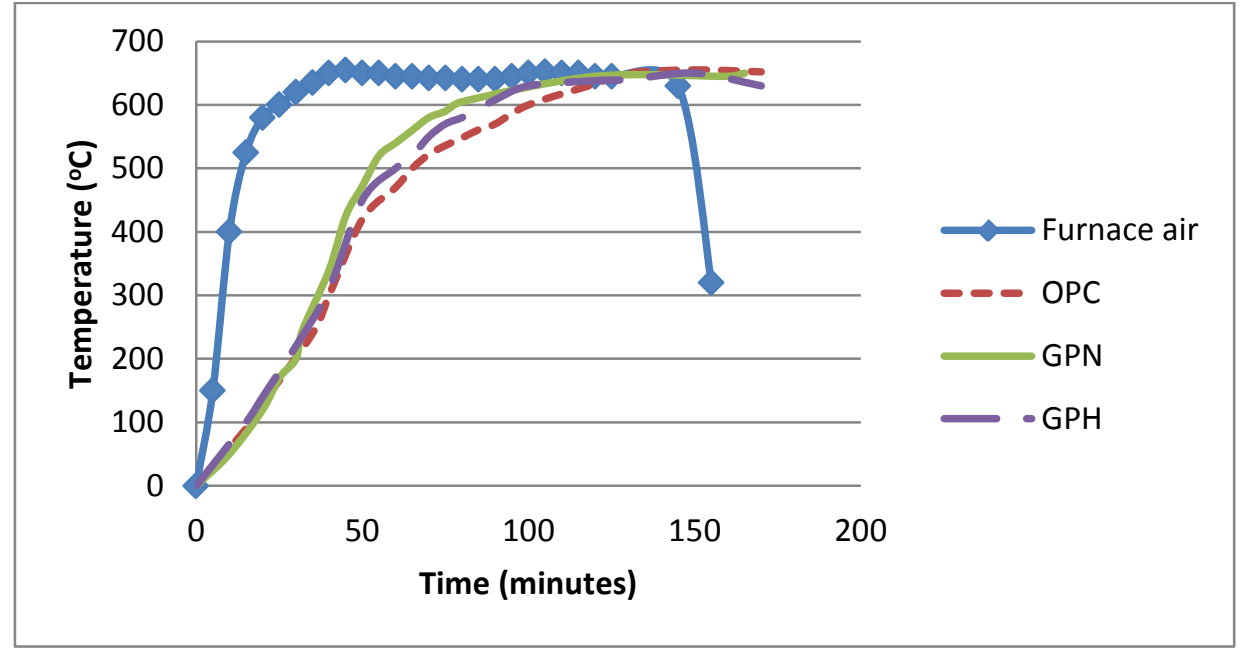

Figure 4. Temperature-time graph in concrete samples exposed to fire at $650{ }^{\circ} \mathrm{C}$ 


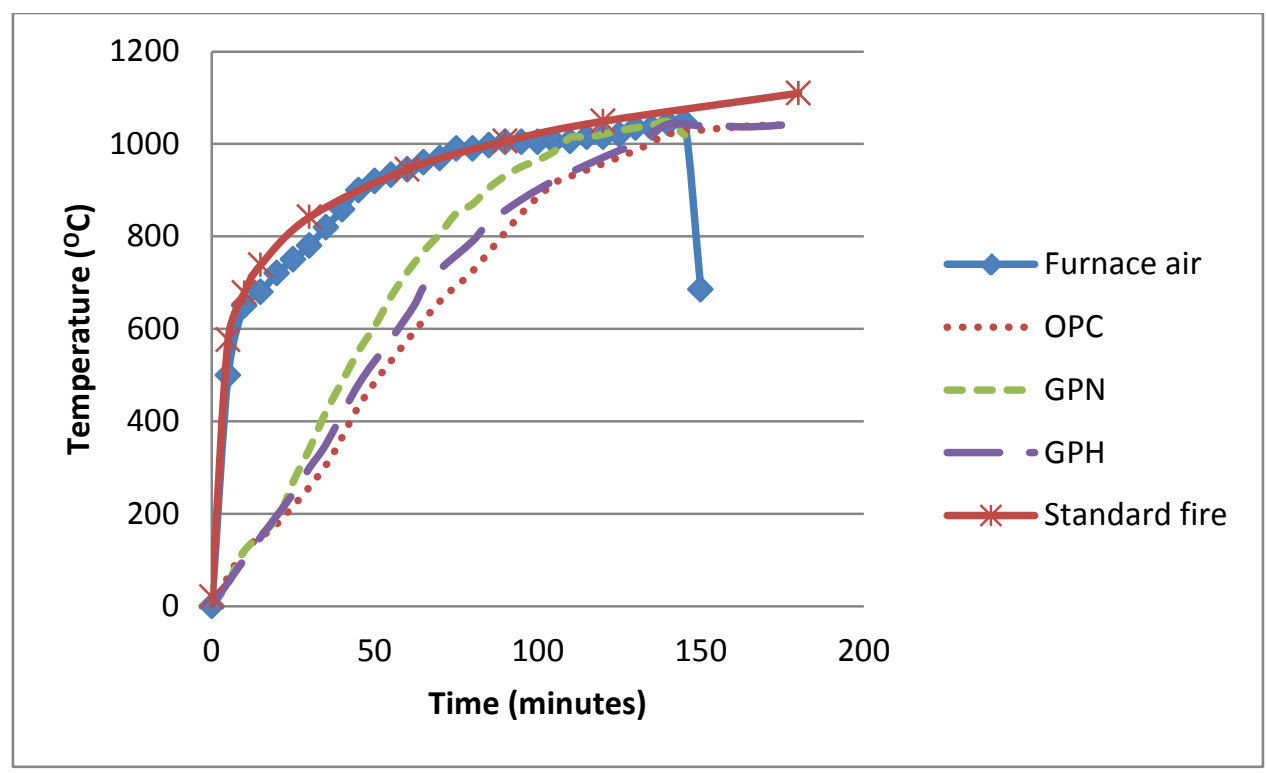

Figure 5. Temperature-time graph in concrete samples exposed to fire at $1000{ }^{\circ} \mathrm{C}$

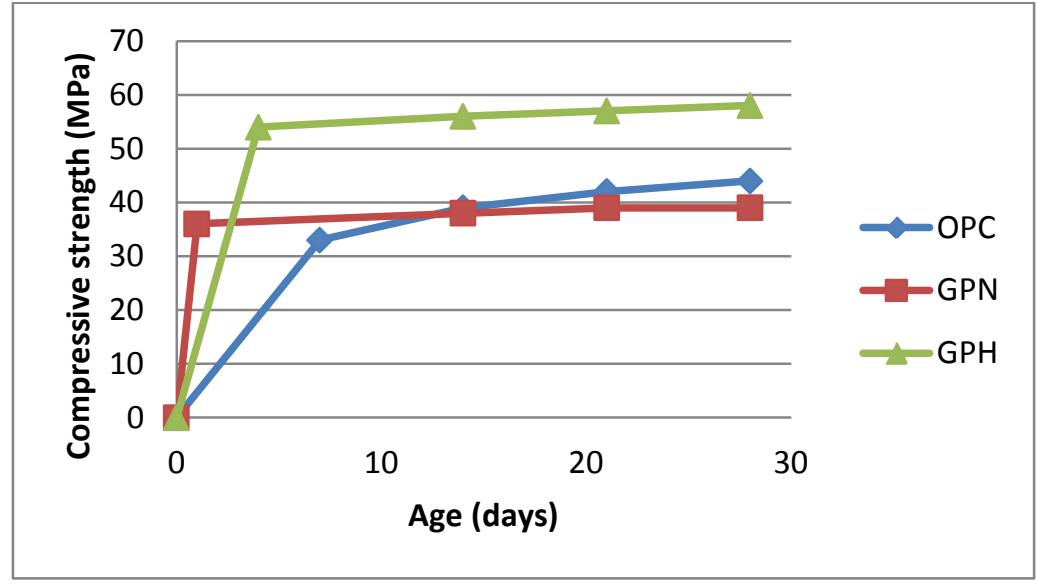

Figure 6. Compressive strength development of the concretes. 


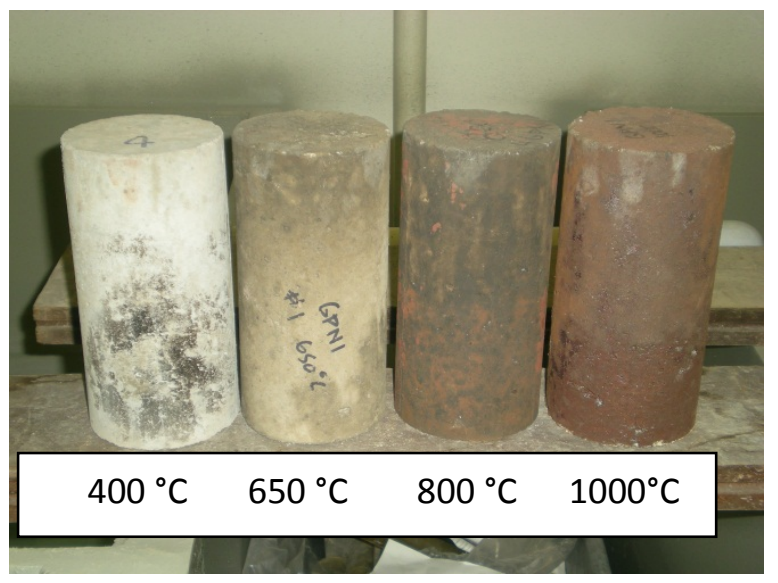

Figure 7. Geopolymer concrete specimens of group GPN after 400, 650, 800 and $1000^{\circ} \mathrm{C}$ exposure

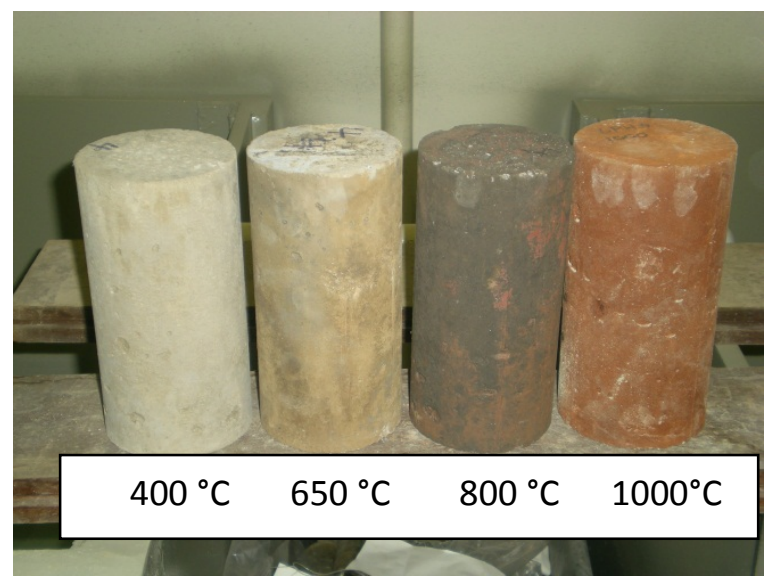

Figure 8. Geopolymer concrete specimens of group GPH after 400, 650, 800 and $1000^{\circ} \mathrm{C}$ exposure.

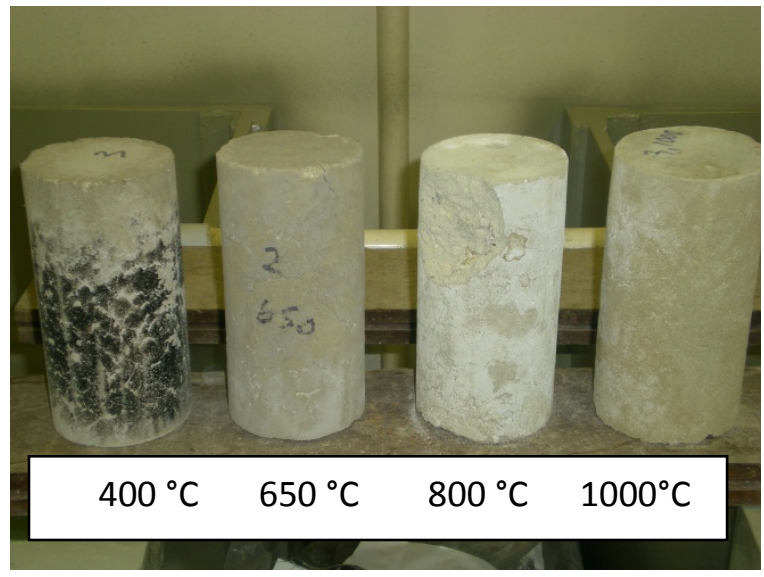

Figure 9. OPC concrete specimens after 400, 650, 800 and $1000{ }^{\circ} \mathrm{C}$ exposure 


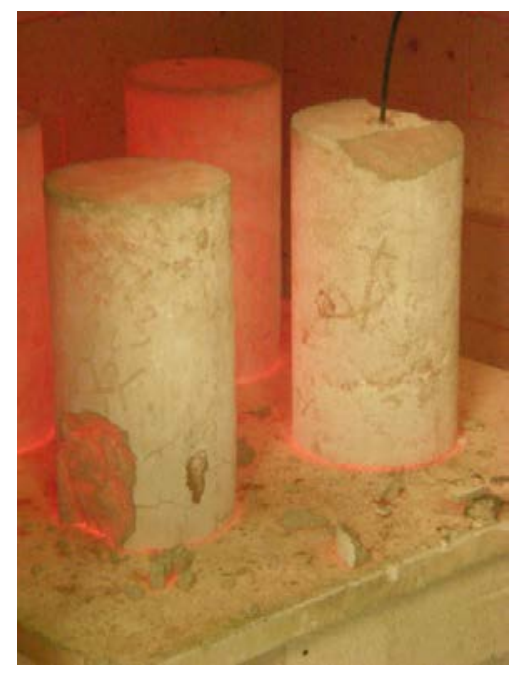

Figure 10. Cracking and spalling of OPC concrete after $800{ }^{\circ} \mathrm{C}$ exposure

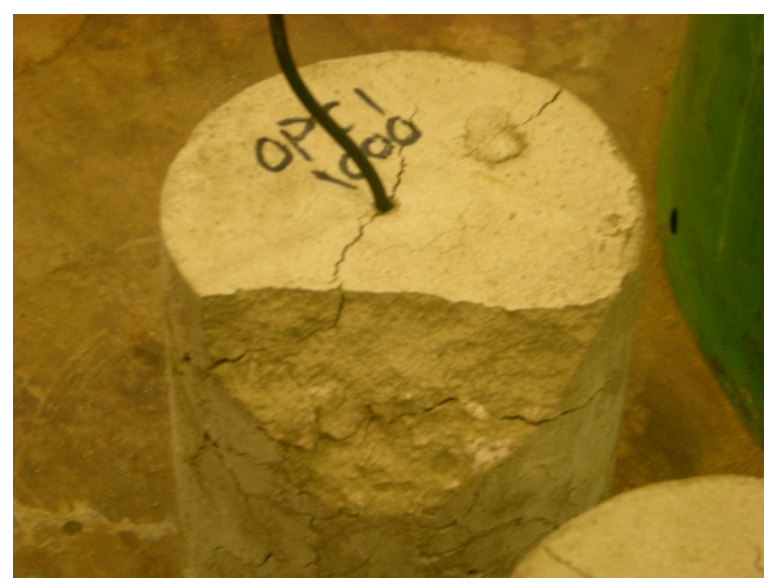

Figure 11. Cracking and spalling of OPC concrete after $1000{ }^{\circ} \mathrm{C}$ exposure

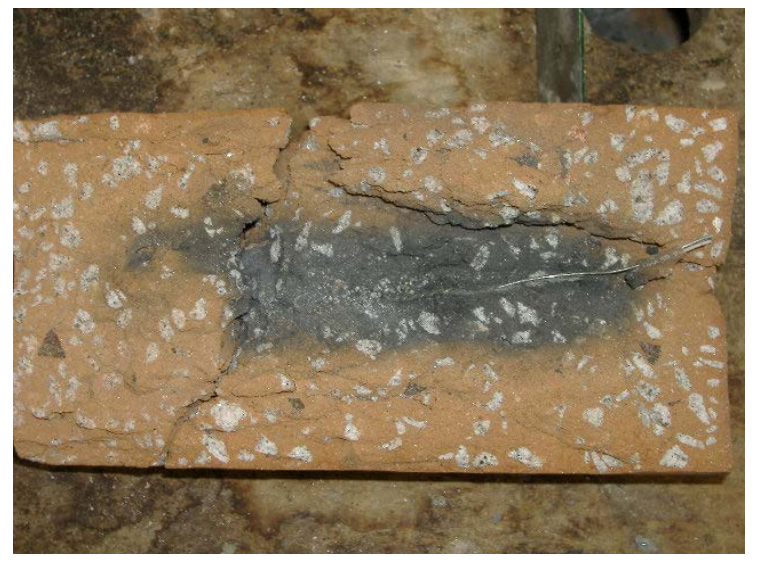

Figure 12. Longitudinal section of geopolymer concrete after $1000^{\circ} \mathrm{C}$ exposure 


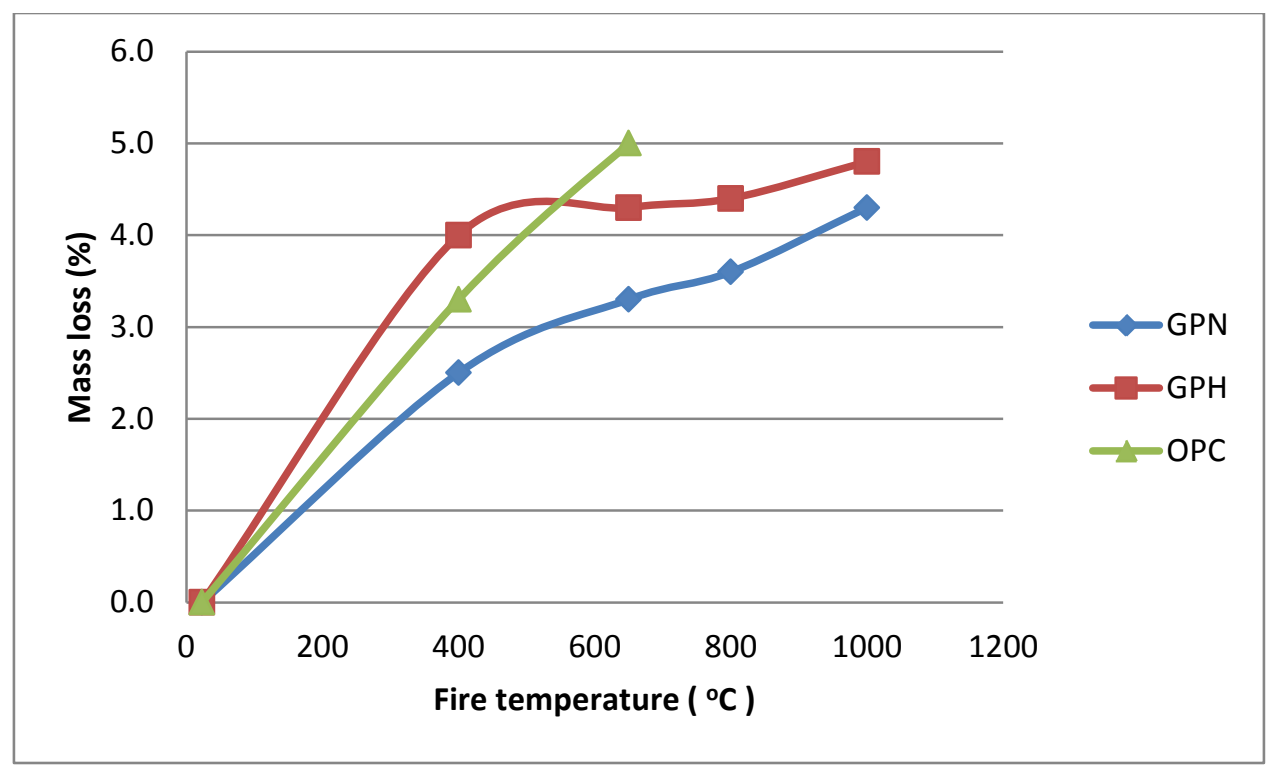

Figure 13. Mass loss of concrete after exposure to fires of different temperature

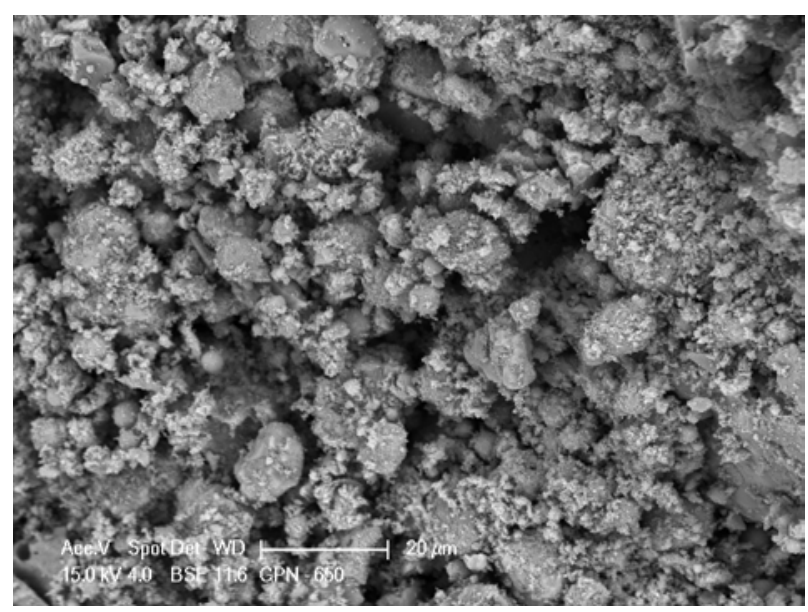

14 (a) 


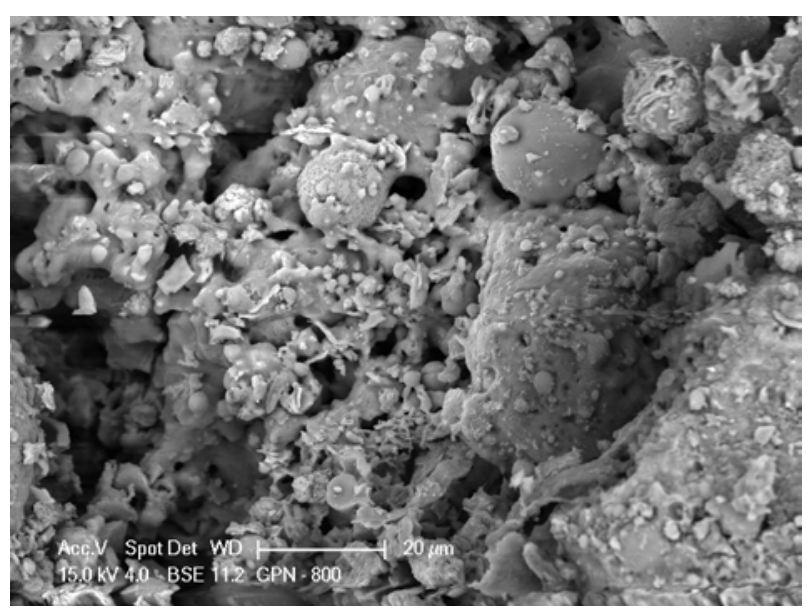

14 (b)

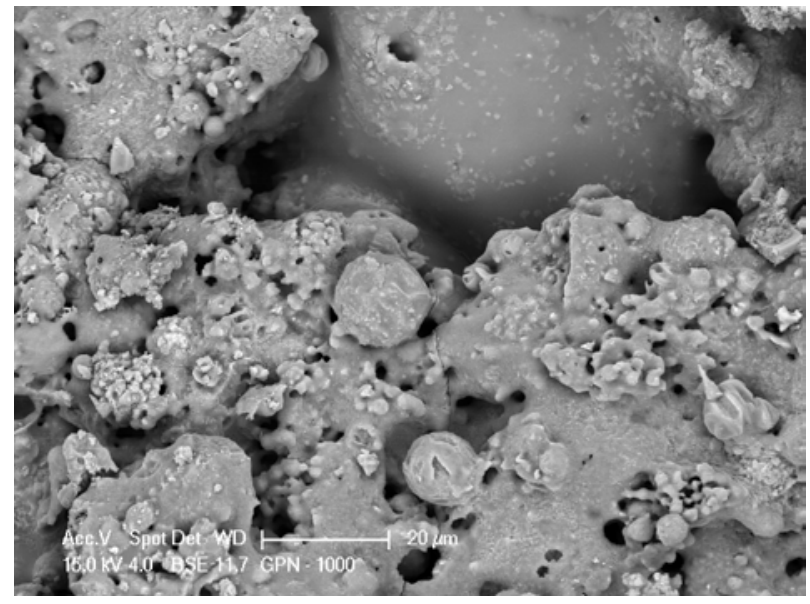

14 (c)

Figure 14. SEM images of GPN specimens after exposure to fire of (a) $650{ }^{\circ} \mathrm{C}$, (b) $800{ }^{\circ} \mathrm{C}$ and (c) $1000^{\circ} \mathrm{C}$ 